\title{
A taxonomic study of the caddisfly Oxyethira falcata Morton, 1893 (Trichoptera: Hydroptilidae) using genital morphology and DNA barcoding
}

\author{
Juha Salokannel, Niklas Wahlberg, Eero J. Vesterinen, Jesus Martinez \& Marcos González
}

Salokannel, J., Wahlberg, N., Vesterinen, E. J., Martinez, J. \& González, M. 2012: A taxonomic study of the caddisfly Oxyethira falcata Morton, 1893 (Trichoptera: Hydroptilidae) using genital morphology and DNA barcoding. Entomol. Fennica 23: 199-205.

Taxonomists have had problems with the hydroptilid caddisfly, Oxyethira falcata Morton, in the past. Four described taxa have been synonymized with $O$. falcata due to considerable intra-specific morphological variation of the male genitalia, and due to misinterpretation of some of the structures of these. In the present study specimens resembling morphologically $O$. boreella Svensson \& Tjeder, one of the synonymized taxa, were compared with the true $O$. falcata using DNA barcoding and studying the male genitalia. Further, a molecular examination of all the Fennoscandian Oxyethira species were carried out, including the rare $O$. klingstedti Nybom, O. tamperensis Malicky, and O. ecornuta Morton. The results support keeping $O$. boreella as a synonym of $O$. falcata. In addition, the DNA analyses showed the presence of monophyletic groups for all of the studied Oxyethira species.

J. Salokannel, Siikinkatu 13, 33710 Tampere, Finland; E-mail: juha.salokannel @gmail.com

N. Wahlberg, Department of Biology, Laboratory of Genetics, University of Turku, 20014 Turku, Finland; E-mail: niklas.wahlberg@utu.fi

E. J. Vesterinen, Department of Biology, Section of Ecology, University of Turku, 20014 Turku, Finland; E-mail: ejvest@utu.fi

J. Martinez \& M. González, Department of Zoology and Physical Anthropology. Faculty of Biology, University of Santiago de Compostela, Santiago de Compostela, 15782, Spain; E-mails: jesus.martinez@usc.es; marcos.gonzalez @usc.es

Received 29 November 2011, accepted 17 January 2012

\section{Introduction}

Oxyethira falcata Morton, 1893 is a tiny hydroptilid species whose west Palaearctic distribution ranges from northern Fennoscandia to North Africa and from the Iberian Peninsula and the Brit- ish Isles to Central Asia and Tibet (Schmid 1960, Ivanov 2011, Tobias \& Tobias 2011). The species inhabits predominantly groundwater feed streams, including small sized rivers, small brooks and trickles. The larval stages of the species are not described, but larvae whose identity 
Table 1. List of Oxyethira specimens examined and sampled for DNA. For the specimens without a Process ID only male genitalia were examined. In column Note, b refers to boreella form and $q$ refers to female specimen.

\begin{tabular}{|c|c|c|c|c|}
\hline Process ID & Species & Note & Country & Region \\
\hline TRIFI155-10 & O. distinctella & & Finland & $\mathrm{Ka}$ \\
\hline TRIFI156-10 & O. distinctella & & Finland & $\mathrm{Ka}$ \\
\hline TRIFI346-11 & O. ecornuta & & Finland & $\mathrm{Kb}$ \\
\hline TRIFI347-11 & O. ecornuta & & Finland & $\mathrm{Kb}$ \\
\hline TRIFI344-11 & O. falcata & & Spain & CyL \\
\hline TRIFI345-11 & O. falcata & $\mathrm{b}$ & Spain & CyL \\
\hline TRIFI106-10 & O. falcata & $\mathrm{b}$ & Finland & $\mathrm{Tb}$ \\
\hline TRIFI109-10 & O. falcata & $\mathrm{b}$ & Finland & $\mathrm{Tb}$ \\
\hline TRIFI110-10 & O. falcata & $\mathrm{b}$ & Finland & $\mathrm{Tb}$ \\
\hline TRIFI111-10 & O. falcata & $\mathrm{b}$ & Finland & $\mathrm{Tb}$ \\
\hline TRIFI112-10 & O. falcata & $\mathrm{b}$ & Finland & $\mathrm{Tb}$ \\
\hline TRIFI113-10 & O. falcata & $\mathrm{b}$ & Finland & $\mathrm{Li}$ \\
\hline TRIFI114-10 & O. falcata & $\mathrm{b}$ & Finland & $\mathrm{Li}$ \\
\hline TRIFI118-10 & O. falcata & & Finland & $\mathrm{Tb}$ \\
\hline TRIFI119-10 & O. falcata & & Finland & $\mathrm{Tb}$ \\
\hline TRIFI125-10 & O. falcata & & Finland & $\mathrm{Sb}$ \\
\hline TRIFI206-10 & O. falcata & & Finland & Le \\
\hline TRIFI207-10 & O. falcata & & Finland & Le \\
\hline TRIFI208-10 & O. falcata & & Finland & Le \\
\hline TRIFI209-10 & O. falcata & & Finland & Le \\
\hline TRIFI213-10 & O. falcata & & Finland & $\mathrm{Li}$ \\
\hline TRIFI214-10 & O. falcata & & Finland & $\mathrm{Li}$ \\
\hline TRIFI636-11 & O. falcata & 우 & Finland & $\mathrm{Li}$ \\
\hline TRIFI637-11 & O. falcata & 우 & Finland & $\mathrm{Li}$ \\
\hline TRIFI638-11 & O. falcata & q & Finland & $\mathrm{Li}$ \\
\hline TRIFI639-11 & O. falcata & 우 & Finland & $\mathrm{Li}$ \\
\hline TRIFI640-11 & O. falcata & 우 & Finland & $\mathrm{Li}$ \\
\hline TRIFI159-10 & O. flavicornis & & Finland & Ok \\
\hline TRIFI160-10 & O. flavicornis & & Finland & $\mathrm{Li}$ \\
\hline TRIFI349-11 & O. frici & & Finland & $\mathrm{Li}$ \\
\hline TRIFI350-11 & O. frici & & Finland & $\mathrm{Li}$ \\
\hline TRIFI165-10 & O. klingstedti & & Finland & $\mathrm{Li}$ \\
\hline TRIFI210-10 & O. klingstedti & & Finland & Le \\
\hline TRIFI211-10 & O. klingstedti & & Finland & Le \\
\hline TRIFI212-10 & O. klingstedti & & Finland & Le \\
\hline TRIFI146-10 & O. mirabilis & & Finland & $\mathrm{Li}$ \\
\hline TRIFI149-10 & O. mirabilis & & Finland & $\mathrm{Li}$ \\
\hline TRIFI148-10 & O. mirabilis & & Finland & $\mathrm{Tb}$ \\
\hline TRIFI154-10 & O. sagittifera & & Finland & $\mathrm{Li}$ \\
\hline TRIFI215-10 & O. sagittifera & & Finland & $\mathrm{Kb}$ \\
\hline TRIFI162-10 & O. simplex & & Finland & $\mathrm{Tb}$ \\
\hline TRIFI163-10 & O. tamperensis & & Finland & Le \\
\hline TRIFI216-10 & O. tamperensis & & Finland & Le \\
\hline TRIFI348-11 & O. tristella & & Finland & $A b$ \\
\hline TRIFI425-11 & O. tristella & & Finland & $A b$ \\
\hline \multirow[t]{9}{*}{ TRIFI424-11 } & O. tristella & & Finland & $\mathrm{Sb}$ \\
\hline & O. falcata & $\mathrm{b}$ & Finland & $\mathrm{Tb}$ \\
\hline & O. falcata & $\mathrm{b}$ & Finland & $\mathrm{Tb}$ \\
\hline & O. falcata & $\mathrm{b}$ & Finland & $\mathrm{Tb}$ \\
\hline & O. falcata & $b$ & Finland & $\mathrm{Tb}$ \\
\hline & O. falcata & $b$ & Finland & $\mathrm{Tb}$ \\
\hline & O. falcata & $\mathrm{b}$ & Finland & $\mathrm{Tb}$ \\
\hline & O. falcata & $\mathrm{b}$ & Finland & $\mathrm{Tb}$ \\
\hline & O. falcata & $\mathrm{b}$ & Finland & $\mathrm{Tb}$ \\
\hline
\end{tabular}




\begin{tabular}{llll}
\hline Process ID & Note & Country & Region \\
\hline & & & \\
O. falcata & $\mathrm{b}$ & Finland & $\mathrm{Tb}$ \\
O. falcata & $\mathrm{b}$ & Finland & $\mathrm{Tb}$ \\
O. falcata & $\mathrm{b}$ & Finland & $\mathrm{Li}$ \\
O. falcata & & Finland & $\mathrm{Li}$ \\
O. falcata & Finland & $\mathrm{Li}$ \\
O. falcata & Finland & $\mathrm{Li}$ \\
O. falcata & Finland & $\mathrm{Li}$ \\
O. falcata & Finland & $\mathrm{Li}$ \\
O. falcata & Finland & $\mathrm{Li}$ \\
O. falcata & Finland & $\mathrm{Li}$ \\
O. falcata & Finland & $\mathrm{Le}$ \\
O. falcata & Finland & $\mathrm{Ks}$ \\
O. falcata & Finland & $\mathrm{Ks}$ \\
O. falcata & Finland & $\mathrm{St}$ \\
O. falcata & Finland & $\mathrm{St}$ \\
O. falcata & & $\mathrm{Tb}$ \\
O. falcata & & $\mathrm{Tb}$ \\
O. falcata & Finland & $\mathrm{Tb}$ \\
O. falcata & Finland & $\mathrm{Tb}$ \\
O. falcata & Finland & $\mathrm{Tb}$ \\
O. falcata & Finland & $\mathrm{Tb}$ \\
O. falcata & Finland & $\mathrm{Tb}$ \\
O. falcata & Finland & $\mathrm{Tb}$ \\
O. falcata & Finland & $\mathrm{Tb}$ \\
O. falcata & Finland & $\mathrm{Tb}$ \\
\hline
\end{tabular}

was confirmed by rearing to adults have been found among submerged macrophytes (P. Wiberg-Larsen, pers. comm.).

Four taxa, O. rhodani Schmid 1947, O. bidentata Nybom 1948 nec Mosely, 1934 (=O. dentata Nybom, 1954 nom. nov.), O. boreella Svensson \& Tjeder 1975, and O. assia Botosaneanu \& Moubayed 1985 were described during the 20th century. All of them were later synonymized with O. falcata by Schmid (1960), Kelley (1984) and Malicky $(2005,2007)$. The descriptions of the new species originate from a peculiar morphological feature of $O$. falcata: a part of the male genitalia may occur in two positions, apparently causing the specimens to look like different species. The explanations for the synonyms in earlier literature are however very brief that they may not prevent new authors from repeating previous mistakes.

One of the synonymized taxa, O. boreella, has been reported from northern Europe: Sweden (Svensson \& Tjeder 1975), Finland (Laasonen \& Laasonen 2000) and north Asia (Morse 2012). Two specimens of a taxon resembling $O$. boreella have also been found in Spain. In this paper, we compare Spanish and Finnish specimens of $O$. falcata (including "O. boreella" specimens), based on the male genitalia and DNA barcodes (Hebert et al. 2003). The purpose is once and for all to confirm the synonymy of the two species. In addition, most other north European Oxyethira species, representing about half of the European species (Malicky 2005), were barcoded as references.

\section{Material and methods}

Specimens from which the DNA barcode was sequenced are given in Table 1. The sequenced $O$. falcata samples were collected from four locations in Finland and one location in Spain. "Oxyethira boreella" samples were collected from two locations in Finland and one location in Spain. Other sequenced Oxyethira material was collected from eight locations in Finland. The Finnish material was mostly caught with Malaise traps using 50\% glycol and stored afterwards in $70 \%$ or $96 \%$ ethanol. 
Total DNA was extracted using QIAgen's DNEasy extraction kit. The DNA barcode region (cytochrome oxidase subunit I) was amplified and sequenced from all specimens using universal primers LCO1490: 5'- GGG TCA ACA AAT CAT AAA GAT ATT GG-3' and HCO2198: 5'TAA ACT TCA GGG TGA CCA AAA AAT CA3' (Folmer et al. 1994). All Polymerase chain reactions (PCR) were performed in $20 \mu \mathrm{l}$ reaction volumes containing $1 \mu \mathrm{l}$ of DNA extract, $12.5 \mu \mathrm{l}$ ddH2O, $2.0 \mu 1$ 10× buffer, $2.0 \mu 1 \mathrm{MgCl} 2,1.0 \mu 1$ primerF (LCO), $1.0 \mu \mathrm{l}$ primerR (HCO), $0.4 \mu \mathrm{l}$ dNTPs, and $0.1 \mu 1$ AmpliTaq Gold polymerase. PCR was performed using following program: 95 ${ }^{\circ} \mathrm{C}$ for $5 \mathrm{~min}, 40 \mathrm{cycles}$ of $94^{\circ} \mathrm{C}$ for $30 \mathrm{sec}, 50^{\circ} \mathrm{C}$ for $30 \mathrm{sec}$, and $72^{\circ} \mathrm{C}$ for $1 \mathrm{~min} 30 \mathrm{sec}$, with a final extension period of $10 \mathrm{~min}$ at $72{ }^{\circ} \mathrm{C}$. Successful PCR products were purified and sequenced by Macrogen Inc. (South Korea). Sequences were trimmed and aligned first using the software Geneious (Drummond et al. 2010) and then manually confirmed by eye.

The resulting sequences were uploaded to TRIFI project in the Barcode of Life Data System (Ratnasingham \& Hebert 2007). The sequences were analyzed in BOLD using the standard neighbour-joining (NJ) method with pairwise distances modified using the K2P model. The tree was downloaded from BOLD server as newick tree and formatted using program TreeGraph2 (Stöver \& Müller 2010). Sequence divergences were calculated on BOLD server.

Further specimens were studied based on the male genitalia alone. These are also presented in Table 1. The morphological study was based on examining the characters of the last segments of male specimens. The genitalia were examined in $70 \%$ or $96 \%$ ethanol or in some cases prepared for glass slides, using a magnification of $20-30 \times$.

\section{Results}

\subsection{Molecular results}

In total 46 Oxyethira samples were successfully sequenced for their DNA barcode. All of the Oxyethira specimens, except $O$. falcata and " $O$. boreella", formed monophyletic groups in the DNA barcode tree (Fig. 1). Oxyethira falcata and

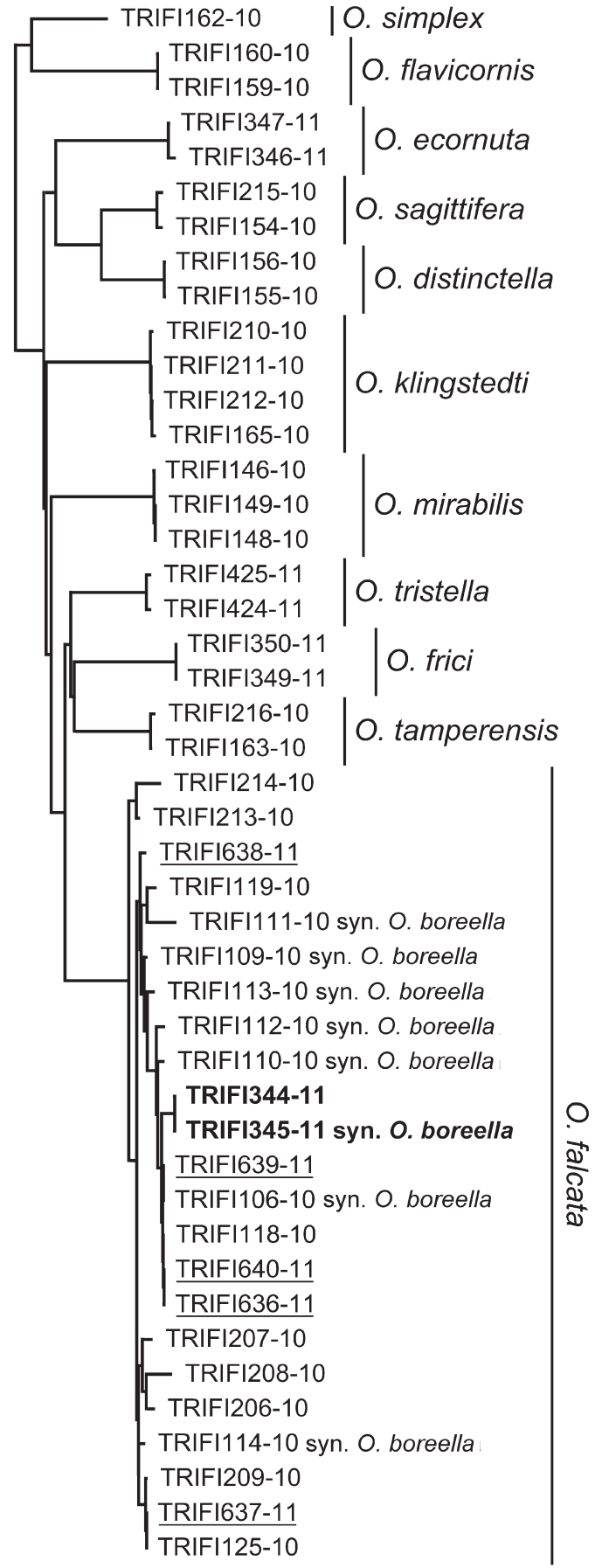

Fig. 1. Neighbour joining tree of partial COI (DNA barcode) gene sequences for Oxyethira species based on genetic distances calculated with the Kimura 2 parameter model. Specimens in bold were collected from Spain, underlined specimens are females. Details for specimens are in Table 1. Scale bar represents $2 \%$ nucleotide divergence. 

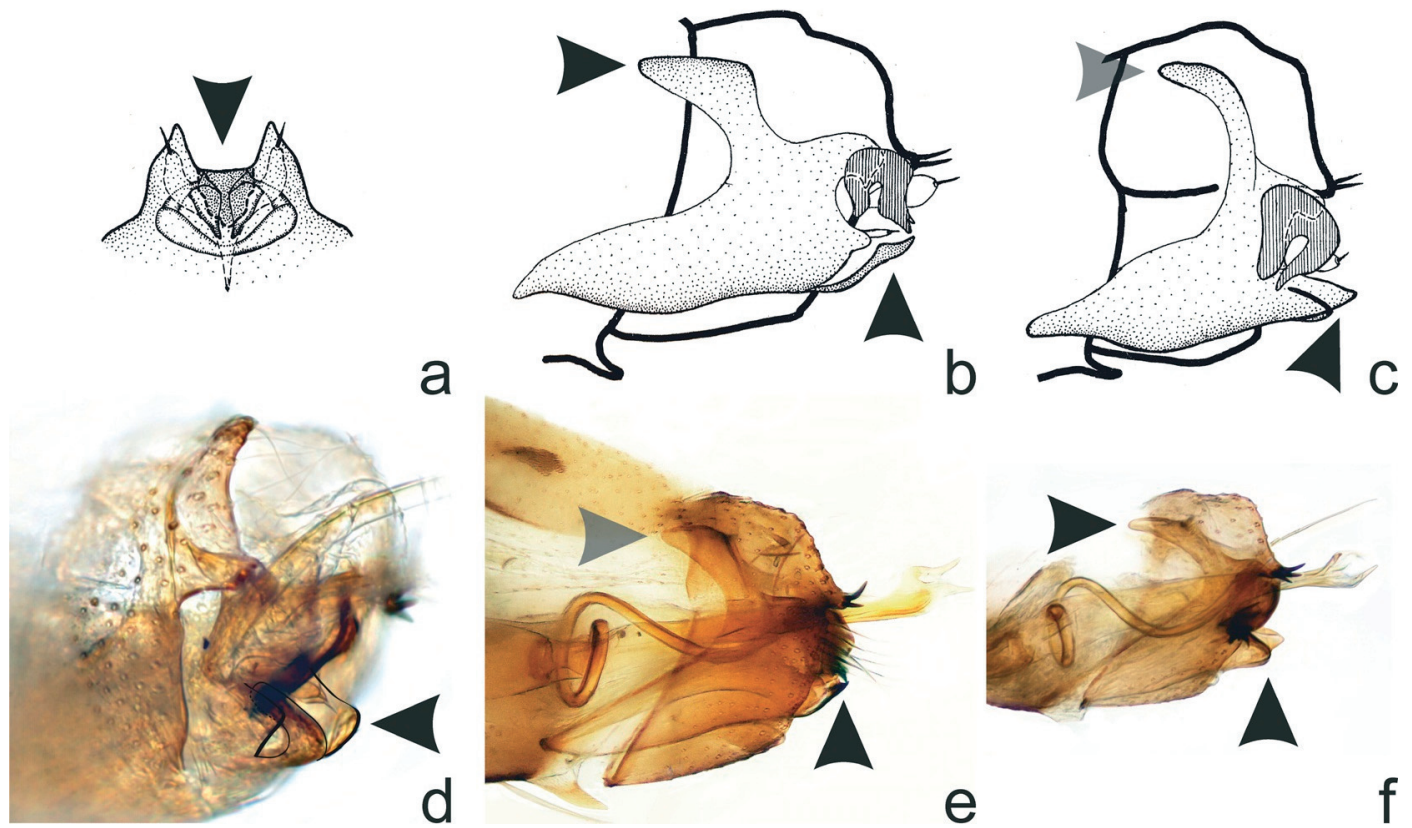

Fig. 2. Morphology of male genitalia of Oxyethira falcata and "boreella" specimens - a. O. boreella: inferior appendages, ventral view (after Kelley, 1985); arrow indicates the "lack" of central lobe. - b. O. falcata: lateral view (after Kelley, 1985); left arrow points to the wide dorsal part of $9^{\text {th }}$ segment and the right arrow points to the inferior appendages of $9^{\text {th }}$ segment. - c. O. boreella: lateral view (after Kelley, 1985); left arrow points to the narrow dorsal part of $9^{\text {th }}$ segment and the right arrow points to the inferior appendages of $9^{\text {th }}$ segment. $-d$. O. falcata ("boreella" specimen from Spain: Candelario, Salamanca): right latero-caudal view; arrow indicates the "lack" of the central lobe. - e. O. falcata, lateral view (specimen from Spain: Candelario, Salamanca); left arrow points to the medium size dorsal part of $9^{\text {th }}$ segment and the right arrow points to the inferior appendages of $9^{\text {th }}$ segment. f. O. falcata ("boreella" specimen from Spain: Candelario, Salamanca): lateral view; left arrow points to the narrow dorsal part of $9^{\text {th }}$ segment and the right arrow points to the inferior appendages of $9^{\text {th }}$ segment.

"O. boreella" were clustered together in one clearly defined monophyletic group, where they could not be distinguished from each other. Indeed, several specimens of "O. boreella" had DNA haplotypes identical with those of $O$. falcata.

\subsection{Morphological results}

In addition to the molecular information, genitalia of 51 male samples of Oxyethira falcataboreella were studied. The specimens were preliminarily identified as $O$. falcata (32 specimens) or "O. boreella" (19 specimens) due to the shape of the inferior appendages in the ventral and lateral view. In the ventral view, the inferior appendages of "O. boreella" specimens had large lateral projecting lobes, but no central process (Figs. 2a, d) (Svensson \& Tjeder 1975), whereas O. falcata had such a central lobe (Fig. 3b). However, when studying the inferior appendages of "O. boreella" specimens more closely, it appears that it actually did have a central lobe.

\section{Discussion}

The molecular results of $O$. falcata group (including "O. boreella" specimens) showed moderate diversity and there was no apparent correlation between the groups of haplotypes and morphological characters. Also, the DNA barcode groups did not directly reflect a geographical pattern: e.g. the Spanish specimens are very similar to central and northern Finnish specimens.

Although according to Svensson and Tjeder (1975) it may be easy to recognize two Oxyethira 

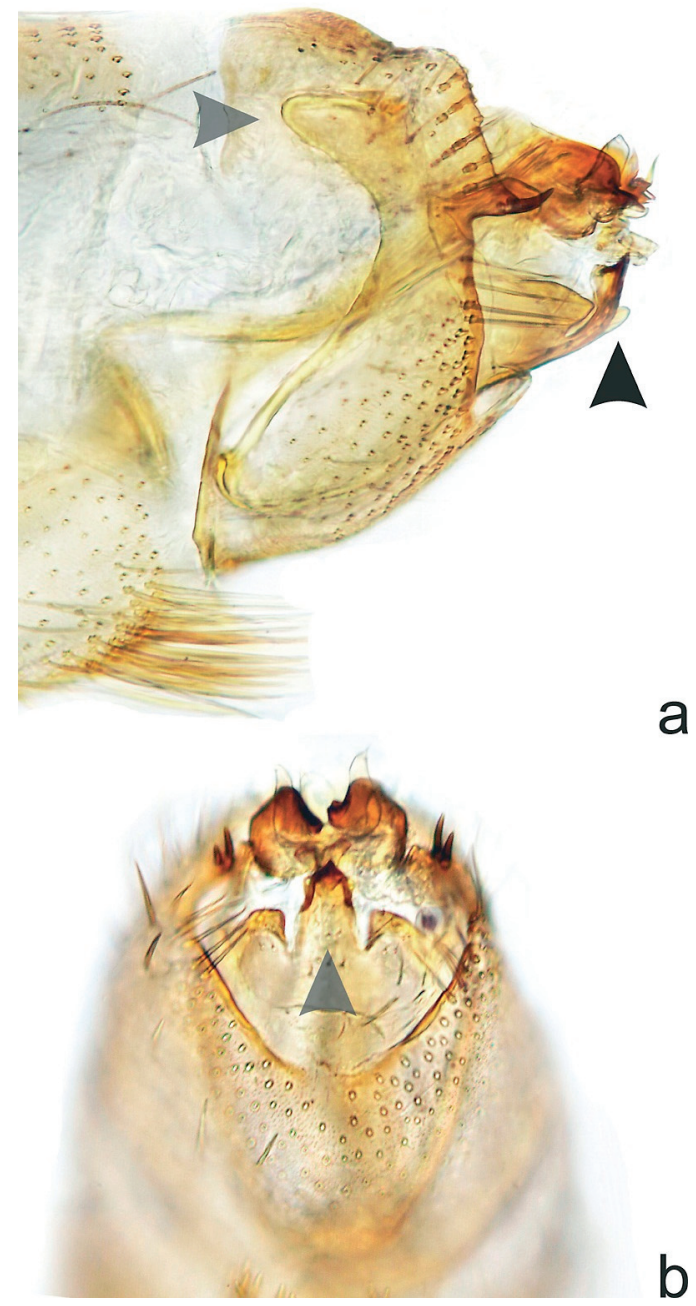

Fig. 3. O. falcata ("boreella" specimen from Finland: Toivakka, Ruostesuo): In this specimen the central lobe was turned after $\mathrm{KOH}$ treatment and a typical "boreella" was thereby transformed into a falcata. - a. Lateral view; left arrow points to the wide dorsal part of $9^{\text {th }}$ segment and right arrow points to the inferior appendages of $9^{\text {th }}$ segment. $-\mathrm{b}$. Ventral view; arrow points to the visible central lobe.

species, boreella and falcata, using characters of the $9^{\text {th }}$ segment and inferior appendages, the main difference between the two is in fact based on how this part of the male genitalia is positioned during preparation. Thus in specimens of " $O$. boreella" the apical process is strongly bent inwards (Figs. 2a, d), causing an illusion of genitalia different from those of $O$. falcata. The reason for the two different positions is however un- known. Our suggestion is that it may depend on whether or not a male has copulated, and that the two positions represent pre- or postmating stages. This could however not be confirmed by the present study. The recognition of two possible positions of the $9^{\text {th }}$ segment in falcata has accordingly been observed by Schmid (1960, p. 99) studying some specimens of $O$. rhodani from Pakistan: "En étudiant mes rhodani pakistanais, j'ai eu l'idée d'introduire une épingle dans l'abdomen traité à la potasse et de pousser les pieces génitales vers l'extérieur. Mes rhodani se sont alors tous transformés en des falcata des plus orthodoxes" translated in English as: "While studying Pakistanese rhodani, I had the idea to introduce a pin in the abdomen after treating it with potassium hydroxide and to push the genitalia outwards. All rhodani then became most perfect falcata". Further, Malicky (2007) came to the same conclusion regarding $O$. falcata and $O$. boreella, but provided no extensive verbal documentation or illustrations.

According to Svensson and Tjeder(1975), the ventral part of the $9^{\text {th }}$ segment (in lateral view) in $O$. boreella should be clearly shorter than in $O$. falcata. In the specimens examined by us, this character varied considerably within and between the two forms (Figs. 2b, c, e, f). Also, the dorsal part of the $9^{\text {th }}$ segment (in lateral view) varied strongly between the two forms (Figs. 2b, c, e, $\mathrm{f}$, and $3 \mathrm{a}$ ). It seems evident that $O$. boreella is just a variation of $O$. falcata.

The results, both molecular and morphological, strongly support keeping $O$. boreella as a synonym for $O$. falcata with the reservation that the type specimens of both species were not studied. Altogether, the DNA barcoding results show monophyletic groups for all of the studied Oxyethira species, including the rare boreal species $O$. ecornuta, $O$. klingstedti and $O$. tamperensis. This result is similar to a recent study on the genus Apatania in Finland that found almost all species to be identifiable using DNA barcodes (Salokannel et al. 2010).

Acknowledgements. Prof. Hans Malicky gave us essential guidance in the morphological questions. Jukka Salmela is thanked for his strong contribution to collecting the majority of the used Finnish Oxyethira specimens in his wide Malaise trap studies and Aki Rinne for sorting Oxyethira individuals out of the vast insect material. We also thank 
two anonymous referees for extensive comments on the manuscript. The study was supported by Vuokon Luonnonsuojelusäätiö (JS) and Suomen Luonnonsuojelun Säätiö (EJV). NW would like to acknowledge funding from the Academy of Finland (grant number 129811) and Koneen Säätiö.

\section{References}

Drummond, A. J., Ashton, B., Buxton, S., Cheung, M., Cooper, A., Heled, J., Kearse, M., Moir, R., StonesHavas, S., Sturrock, S., Thierer, T. \& Wilson, A. 2010: Geneious v 5.1. Available from http://www.geneious.com.

Folmer, O., Black, M., Hoeh, W., Lutz, R. \& Vrijenhoek, R. 1994: DNA primers for amplification of mitochondrial cytochrome c oxidase subunit I from diverse metazoan invertebrates. - Molecular Marine Biology and Biotechnology 3: 294-299.

Hebert, P. D. N., Cywinska, A., Ball, S. L. \& deWaard, J. R. 2003: Biological identifications through DNA barcodes. - Proceedings of the Royal Society B: Biological Sciences 270: 313-321.

Kelley, R. W. 1984: Phylogeny, Morphology and Classification of the Micro-Caddisfly Genus Oxyethira Eaton (Trichoptera: Hydroptilidae). - Transactions of the American Entomological Society 110: 435-463.

Kelley, R. W. 1985: Revision of the Micro-Caddisfly Genus Oxyethira (Trichoptera: Hydroptilidae). Part II: Subgenus Oxyethira. - Transactions of the American Entomological Society 111: 223-253.

Ivanov, V. D. 2011: Caddisflies of Russia: Fauna and biodiversity. - Zoosymposia 5: 171-209.
Laasonen, E. M. \& Laasonen, L. 2000: Short reports. Trichoptera. - Entomologica Fennica 11: 2.

Malicky, H. 2005: Ein kommentiertes Verzeichnis der Köcherfliegen (Trichoptera) Europas und des Mediterrangebietes. — Linzer Biologische Beiträge 37: 533 596.

Malicky, H. 2007: Additions and corrections to the Atlas of European Caddisflies and the corresponding list. Braueria 34: 51-52.

Morse, J.C. (ed.) 2012: Trichoptera World Checklist (version 1). [www document] URL http://entweb.clemson.edu/database/trichopt/index.htm (Site visited on 28 February, 2012).

Ratnasingham, S. \& Hebert, P. D. N. 2007: BOLD: The Barcode of Life Data System (www.barcodinglife.org). - Molecular Ecology Notes 7: 355-364.

Schmid, F. 1960: Trichoptères du Pakistan. 3me partie (Hydroptilidae, Philopotamidae, Polycentropodidae). — Tijdschrift voor Entomologie 103: 83-109.

Salokannel, J., Rantala, M. J., \& Wahlberg, N. 2010: DNAbarcoding clarifies species definitions of Finnish Apatania (Trichoptera: Apataniidae) — Entomologica Fennica 21: 1-11.

Stöver, B. C. \& Müller, K. F. 2010: TreeGraph 2: Combining and visualizing evidence from different phylogenetic analyses. - BMC Bioinformatics 11: 7.

Svensson, B. W. \& Tjeder, B. 1975: Oxyethira boreella $\mathbf{n}$. sp. from Northern Sweden (Trichoptera: Hydroptilidae). - Insect Systematics \& Evolution 6: 131-133.

Tobias, D. \& Tobias, W. 2008: Trichoptera Africana. [www document]. URL http://deposit.d-nb.de/cgibin/dokserv?idn=983001952. (Site visited on 25 November, 2011). 